\title{
Disease control in general practice patients with asthma
}

\section{Hanneke A.H. Wijnhoven, Didi M.W. Kriegsman*, Arlette E. Hesselink, Marten de Haan, Wim Stalman}

Department of General Practice and Institute for Research in Extramural Medicine (EMGO Institute), Vrije Universiteit Medical Centre (D539), Van der Boechorststraat 7, Amsterdam 1081 BT,

The Netherlands

\author{
KEYWORDS \\ Respiratory symptom; \\ PEF variability; \\ $\mathrm{FEV}_{1}$; \\ Disease control; \\ Asthma
}

\section{Introduction}

A recent multinational survey showed that asthma control is sub-optimal for many people in Western

\footnotetext{
*Corresponding author. Tel.: +31-20-4448194; fax: +31-20-4448361.

E-mail address: dmw.kriegsman.emgo@med.vu.nl (D.M.W. Kriegsman).
}

Summary Objectives: To examine asthma control in conjunction with medication use in asthma patients from general practice. To determine features of patients with inadequately controlled asthma.

Methods: A cross-sectional study was performed among 661 adult asthma patients recruited from general practice. Disease control was defined by: (1) respiratory symptoms; (2) forced expiratory volume in $1 \mathrm{~s}\left(\mathrm{FEV}_{1}\right) \%$ predicted; (3) PEF variability; and (4) the use of $\beta 2$-agonists. Medical treatment was categorised according to the step-care therapy rules following the 1997 guideline of the Dutch College of General Practitioners (DDGP).

Results: Of the 661 asthma patients studied, $262(40 \%)$ had a good disease control, $84(13 \%)$ a mildly reduced, $235(36 \%)$ a moderately reduced, and $80(12 \%)$ had a poor disease control. Of the 399 patients $(60 \%)$ inadequately controlled, in 292 patients (44\%) adequate control might be achieved by changing treatment, in 99 patients (15\%) adequate control might not completely be achieved by changing treatment, and $8(1 \%)$ were already maximally treated. Compared to patients with a good disease control, patients inadequately controlled were usually older, less educated, younger at onset of pulmonary complaints, and in addition had more severe dyspnea and poorer health-related quality of life (HRQoL).

Conclusion: Using our criteria, a substantial proportion of asthma patients primarily treated in general practice is not adequately controlled. Assessing patients' disease control together with the level of medical treatment may help to gain insight into the effectiveness of current disease management.

(c) 2003 General Practice Airways Group. Published by Elsevier Ltd. All rights reserved.
Europe [1]. In this study, we examine the level of disease control in an asthma population recruited from Dutch general practices. The level of disease control was related to the amount of asthma medication used in order to estimate how many of the inadequately controlled patients might benefit from changing treatment. In addition, features of patients not adequately controlled were examined in order to create a risk-profile of use for the general practitioner. 


\section{Methods}

The study has a cross-sectional design. An extensive description of the study population and methods of measurements can be found elsewhere [2]. A short description of patients and measurements will be given here.

\section{Patients}

General practices in three regions of The Nether lands selected all patients registered with a diagnosis of asthma and COPD [2].For the present study, from the total group of asthma and COPD patients included in the longitudinal study, asthma patients were selected, using the 1997 diagnostic guidelines of the Dutch College of General Practitioners (DDGP) [3]. Asthma was defined as: (1) a pre-forced expiratory volume in $1 \mathrm{~s}\left(\mathrm{FEV}_{1}\right) \%$ predicted $\geq 80 \%$; or (2) a combination of a pre-percentage of the predicted $\mathrm{FEV}_{1}\left(\mathrm{FEV}_{1} \%\right.$ predicted) $<80 \%$, a reversible obstruction ( $\geq 9 \%$ of predicted), and a post- $\mathrm{FEV}_{1} \%$ predicted $\geq 80 \%[2]$.

\section{Measurements}

Forced expiratory volume in $1 \mathrm{~s}$ was measured according to ATS criteria [4] before (pre-FEV ${ }_{1}$ ) and after (post-FEV ${ }_{1}$ ) administration of a bronchodilator [2]. $\mathrm{FEV}_{1}$ was expressed as a percentage of the predicted $\mathrm{FEV}_{1}$ using the adult predicted normals of the European Community for Coal and Steel [5].

A 2-week diary chart, including questions on respiratory symptoms, use of bronchodilators, and peak flow assessment, was handed out to the patient to be completed at home. Peak expiratory flow (PEF) was measured every morning and evening three times in standing position with the 'Personal Best Peak Flow meter' (Respironics Inc., Pittsburgh, USA). Each day, the single best morning and evening PEF were noted on the diary chart. Variability in PEF was expressed as the mean diurnal (within-day) PEF variation [(highest PEF - lowest PEF)/[(morning PEF+ evening PEF) $/ 2] \times 100$, averaged over 14 days]. Each day, the patient also recorded whether the past day and night were disturbed by pulmonary complaints. In the morning, the patient had to record if, in the past night, he or she had woken up due to pulmonary complaints (yes or no). In the evening, the patient had to record if, during the day, he or she had skipped school or work or had been restricted in daily activities due to pulmonary complaints (yes or no). Additionally, pa- tients recorded the number of times bronchodilators had been used in the past $24 \mathrm{~h}$. For all scores calculated, data were extrapolated in case of missing data when at least 10 days provided valid data.

Medication use was assessed by asking patients which kind of medication they used and in which dose they used this medication. The amount of medical treatment was then categorised according to the stepped-care therapy rules of the 1997 guidetines of the DCGP for the treatment of asthma [6]. This stepped-care therapy recommends which kind of medication should be used according to the severity of the disease (Table 2). Compliance with the use of inhaled anti-inflammatory agents was assessed by means of a three-item checklist. Patients were considered non-compliant if they in the last 3 months ever: (1) forgot using their medication; (2) stopped using their medication because they felt better; (3) used less medication than prescribed because they felt better. Inhalation technique (sufficient or insufficient) was scored by means of a short three-item version of the validated, inhalerspecific checklist of the Dutch Asthma Foundation [7].

Health-related quality of life (HRQoL) was measured using the disease specific Quality Of Life in Respiratory Illness Questionnaire (QOL-RIQ) [8]. It comprises 55 items, categorised under seven subscales and an overall score. For every item, patients are asked to answer, on a seven-point Likert-type scale, to what degree they are bothered by pulmonary complaints (from 1: not bothered at all, to 7: very much bothered).

Information was obtained on age (years), age at onset of pulmonary complaints (years), gender, and educational level (low, medium, high) [2]. Co-morbidity was defined present if the patient reported any other chronic disease (such as diabetes mellitus, hypertension, cardiovascular disease, stroke, arthritis, or malignancies). Cigarette smoking habits were defined by assessing smoking status (never, former, current). Allergy was defined present by a positive Phadiatop test (Pharmacia $A B$, Uppsala, Sweden) [9].

The degree of dyspnea (no dyspnea, dyspnea when in a hurry, dyspnea when walking with others on flat ground, having to stop for breath when walking alone on flat ground or dyspnea in rest) was assessed using the Dutch version of Medical Research Council (MRC) questionnaire [10]. In addition, information was obtained on: (1) wheezing (never, ever, most days and nights); (2) chronic cough (present, not present); and (3) sputum production (present, not present) [2]. 


\section{Assessment of asthma control}

We used: (1) respiratory symptoms during day and night $[11,12]$, (2) $\mathrm{FEV}_{1} \%$ predicted [11,12], (3) PEF variability [11], and (4) the use of $\beta 2$-agonists [12] to define disease control. Categorisation into dif- ferent levels of disease control was done separately for each criterion and for all criteria together using the worst categorisation [12]. The worst categorisation means for example that when a patient has good disease control according to the $\mathrm{FEV}_{1}$, PEF variability, and day- and night-time symptoms, but

Table 1 Level of disease control: classification rules (adopted from NAEPP Expert Panel Report II [1] and Colice et al. [12]).

\begin{tabular}{|c|c|c|c|c|c|}
\hline & Symptoms ${ }^{a}$ & $\begin{array}{l}\text { Night-time } \\
\text { symptoms [1] }\end{array}$ & $\begin{array}{l}\mathrm{FEV}_{1} \% \\
\text { predicted }\end{array}$ & $\begin{array}{l}\text { PEF variability } \\
\text { [1] (\%) }\end{array}$ & $\beta 2$-agonist use [1] \\
\hline Good disease control & $\leq 4$ days & $\leq 1$ night & $\geq 80$ & $<20$ & On $\leq 4$ days \\
\hline $\begin{array}{l}\text { Mildly reduced } \\
\text { disease control }\end{array}$ & $\begin{array}{l}>4 \text { days, } \\
<14 \text { days }\end{array}$ & 2 nights & $\geq 80$ & $20-30$ & $\begin{array}{l}>0 \text { uses on }>4 \text { days, } \\
\text { but }<14 \text { days }\end{array}$ \\
\hline $\begin{array}{l}\text { Moderately reduced } \\
\text { disease control }\end{array}$ & 14 days & $\begin{array}{l}>2 \text { nights, } \\
<8 \text { nights }\end{array}$ & $>60-\leq 80$ & $>30$ & $\begin{array}{l}>0 \text { uses on } 14 \text { days, } \\
\text { but } \leq 2 \text { uses on at } \\
\text { least } 1 \text { day }\end{array}$ \\
\hline Poor disease control & 14 days & $\geq 8$ nights & $\leq 60$ & $>30$ & $\begin{array}{l}>2 \text { uses on each of } \\
\text { the } 14 \text { days }\end{array}$ \\
\hline
\end{tabular}

a Per 2 weeks.

Table 2 Level of disease control according to 'worst category' vs. medical treatment.

Disease control Medical treatment according to the step-care therapy rules [9]

\begin{tabular}{|c|c|c|c|c|c|}
\hline & Step 0 & $\begin{array}{l}\text { Step 1: } \\
\text { Short-acting } \\
\beta 2 \text {-agonists if } \\
\text { necessary }\end{array}$ & $\begin{array}{l}\text { Step } 2^{\mathrm{a}} \text { : Low } \\
\text { dose [2] inhaled } \\
\text { corticosteroids or } \\
\text { cromoglycine }\end{array}$ & $\begin{array}{l}\text { Step } 3^{a}:(1) \text { High } \\
\text { dose }{ }^{b} \text { inhaled } \\
\text { corticosteroids; } \\
\text { or }(2) \text { moderate } \\
\text { dose }^{b} \text { inhaled } \\
\text { corticosteroids }_{\text {and long-acting }} \\
\beta 2 \text {-agonists }\end{array}$ & $\begin{array}{l}\text { Step } 4^{\mathrm{a}} \text { : }(1) \text { High } \\
\text { dose }^{\mathrm{b}} \text { inhaled } \\
\text { corticosteroids } \\
\text { combined with } \\
\text { long-acting } \\
\beta 2 \text {-agonists or } \\
\text { ipratropiumbro- } \\
\text { mide; or (2) oral } \\
\text { steroids }\end{array}$ \\
\hline Good $^{c}$ & $\begin{array}{l}\text { Wrongly labeled } \\
\text { as asthma }\end{array}$ & $\begin{array}{l}\text { Mild intermittent } \\
\text { disease severity }\end{array}$ & $\begin{array}{l}\text { Mild persistent } \\
\text { disease severity }\end{array}$ & $\begin{array}{l}\text { Moderate } \\
\text { persistent } \\
\text { disease severity }\end{array}$ & $\begin{array}{l}\text { Severe persistent } \\
\text { disease severity }\end{array}$ \\
\hline Mildly reduced & $\begin{array}{l}\text { Undertreatment } \\
\text { by one dose level }\end{array}$ & $\begin{array}{l}\text { Undertreatment } \\
\text { by one dose level }\end{array}$ & $\begin{array}{l}\text { Undertreatment } \\
\text { by one dose level }\end{array}$ & $\begin{array}{l}\text { Undertreatment } \\
\text { by one dose level }\end{array}$ & $\begin{array}{l}\text { Adequate control } \\
\text { cannot be } \\
\text { achieved }\end{array}$ \\
\hline $\begin{array}{c}\text { Moderately } \\
\text { reduced }\end{array}$ & $\begin{array}{l}\text { Undertreatment } \\
\text { by two dose } \\
\text { levels }\end{array}$ & $\begin{array}{l}\text { Undertreatment } \\
\text { by two dose } \\
\text { levels }\end{array}$ & $\begin{array}{l}\text { Undertreatment } \\
\text { by two dose } \\
\text { levels }\end{array}$ & $\begin{array}{l}\text { Undertreatment } \\
\text { by one dose } \\
\text { levels/adequate } \\
\text { control cannot be } \\
\text { achieved }\end{array}$ & $\begin{array}{l}\text { Adequate control } \\
\text { cannot be } \\
\text { achieved }\end{array}$ \\
\hline Poor & $\begin{array}{l}\text { Undertreatment } \\
\text { by three dose } \\
\text { levels }\end{array}$ & $\begin{array}{l}\text { Undertreatment } \\
\text { by three dose } \\
\text { levels }\end{array}$ & $\begin{array}{l}\text { Undertreatment } \\
\text { by two dose } \\
\text { levels/adequate } \\
\text { control cannot be } \\
\text { achieved }\end{array}$ & $\begin{array}{l}\text { Undertreatment } \\
\text { by one dose } \\
\text { levels/adequate } \\
\text { control cannot be } \\
\text { achieved }\end{array}$ & $\begin{array}{l}\text { Adequate control } \\
\text { cannot be } \\
\text { achieved }\end{array}$ \\
\hline
\end{tabular}

${ }^{a}$ Including short-acting $\beta 2$-agonists if necessary.

${ }^{b}$ For beclometason and budesonide, low dose was 200-400 $\mu \mathrm{g} 2 \mathrm{dd}$, moderate dose was 400-800 $\mu \mathrm{g} 2 \mathrm{dd}$, and high dose was $>800 \mu \mathrm{g} 2 \mathrm{dd}$. For fluticason, low dose was $100-250 \mu \mathrm{g} 2 \mathrm{dd}$, moderate dose was $250-500 \mu \mathrm{g} 2 \mathrm{dd}$, and high dose was $>500 \mu \mathrm{g} 2 \mathrm{dd}$.

${ }^{c}$ In case of adequate disease control (mild intermittent), the amount of medical treatment indicates global disease severity (mild intermittent trough severe persistent). 
uses $\beta 2$-agonists more than twice a day, the patient is categorised in the group of poor disease control.

\section{Statistical analyses}

Data were analysed using the statistical package SPSS.7.5. Classification rules for describing the level of disease control can be found in Table 1 . The level of disease control was cross-tabulated with the amount of medical treatment (true-use), which was categorised according to the step-care therapy rules of the DCGP-guideline [6] (Table 2). With this cross-tabulation, we were able to classify disease severity in patients with adequate disease control, identify patients not adequately treated (separated in patient in which adequate control may be achieved by changing treatment and patients in which adequate control might not be achieved by changing treatment), and identify patients with inadequate disease control despite maximum treatment.

Determinants of the following patient groups were examined (reference group: good asthma control using anti-asthma medication): (1) good asthma control not using anti-asthma medication; (2) inadequate control, adequate control may be achieved by changing treatment; (3) inadequate control, adequate control might not be achieved. Determinants were examined using bivariate and multivariate multinomial logistic regression techniques with patient groups as the dependent variable and demographic and asthma characteristics as the independent variables. Since HRQoL is rather an outcome measure than a determinant, its associ- ation with patient groups was examined bivariately but it was not included in the multivariate model.

\section{Results}

A total of 2047 patients with asthma or COPD were selected by the general practitioners. Of them, 722 (mean age, 43 years; $50 \%$ male) refused to participate, leaving 1325 patients (mean age, 46 years; $44 \%$ male). Another 13 patients were excluded because they did not perform the pulmonary function test. Of the 1312 patients left, 963 were defined as asthma patients. After exclusion of all missing data, 661 patients were included in the present study. Patients excluded due to missing data appeared to be younger (mean age, 41 years) than patients included (mean age, 45 years). No differences were found regarding gender, pulmonary function and medical treatment (Table 3), although excluded patients tended to have a lower level of medical treatment $(P=0.08)$.

Table 4 describes the level of disease control in the study population according to classification rules presented in Table 1 . When the worst classification was used, $262(39.6 \%)$ asthma patients appeared to have a good disease control, $84(12.7 \%)$ a mildly reduced, 235 (35.6\%) a moderately reduced, and $80(12.1 \%)$ a poor disease control. A poor correlation was found between individual variables in categorising the level of disease control. Cohen's kappa's [13] ranged from 0.01 to 0.15 , indicating poor agreement (data not shown). We found that the use of $\beta 2$-agonists and night-time symptoms

Table 3 Characteristics of all asthma patients selected $(n=963)$ separately for patients included $(n=661)$ and patients excluded $(n=302)$ due to missing data ${ }^{a}$.

\begin{tabular}{|c|c|c|c|}
\hline Characteristics & $\begin{array}{l}\text { Asthma patients } \\
\text { included }(n=661)\end{array}$ & $\begin{array}{l}\text { Asthma patients } \\
\text { excluded }(n=302)\end{array}$ & $P$-value \\
\hline Age (years) & $45(15)$ & $41(15)$ & 0.002 \\
\hline Male gender & 38 & 42 & 0.37 \\
\hline $\begin{array}{l}\text { Prebronchodilator } \mathrm{FEV}_{1} \% \\
\text { predicted }\end{array}$ & $95.9(14.9)$ & $96.3(13.9)$ & 0.66 \\
\hline \multicolumn{4}{|l|}{ Medical treatment ${ }^{\mathrm{b}}$} \\
\hline Step 0 & 21.3 & 24.7 & \multirow[t]{6}{*}{0.08} \\
\hline Step 1 & 18.2 & 19.7 & \\
\hline $\begin{array}{l}\text { Step 2, corticosteroids } \\
\text { when necessary }\end{array}$ & 12.2 & 18.0 & \\
\hline Step 2 & 37.2 & 27.0 & \\
\hline Step 3 & 9.7 & 9.7 & \\
\hline Step 4 & 1.4 & 1.0 & \\
\hline
\end{tabular}


Table 4 Level of disease control: number of asthma patients $(n=661)$.

\begin{tabular}{|c|c|c|c|c|c|c|}
\hline & Symptoms [1] & $\begin{array}{l}\text { Night-time } \\
\text { symptoms [1] }\end{array}$ & $\begin{array}{l}\mathrm{FEV}_{1} \\
\text { predicted }\end{array}$ & $\begin{array}{l}\text { PEF } \\
\text { variability }\end{array}$ & $\begin{array}{l}\beta 2 \text {-agonist } \\
\text { use }\end{array}$ & $\begin{array}{l}\text { Worst } \\
\text { category }\end{array}$ \\
\hline Good disease control & $608(92.0)$ & $439(66.4)$ & $577(87.3)$ & $644(97.4)$ & $369(55.8)$ & $262(39.6)$ \\
\hline $\begin{array}{l}\text { Mildly reduced } \\
\text { disease control }\end{array}$ & $43(6.5)$ & 52 (7.9) & & $13(2.0)$ & $108(16.3)$ & $84(12.7)$ \\
\hline $\begin{array}{l}\text { Moderately reduced } \\
\text { disease control }\end{array}$ & $10(1.5)$ & $126(19.1)$ & $81(12.3)$ & $4(0.6)$ & $140(21.2)$ & $235(35.6)$ \\
\hline Poor disease control & & $44(6.7)$ & $3(0.5)$ & & $44(6.7)$ & $80(12.1)$ \\
\hline
\end{tabular}

were most dominant in determining the lever of disease control. Cohen's kappa was 0.63 for use of $\beta 2$-agonists versus the level of disease control, 0.50 for night-time symptoms, and it ranged from 0.02 to 0.26 for the other variables (data not shown).

In Table 5 , one can see the level of disease control according to the worst categorisation in conjunction with the level of medical treatment as described in Table 2. It appeared that 262 (39.6\%) patients had good disease control, 292 (44.2\%) were not adequately treated, but by changing treatment adequate control may be achieved, 99 (15.0\%) were not adequately treated, but adequate control might not completely be achieved by changing treatment, and $8(1.2 \%)$ were considered as patients in which adequate control can not be achieved since they did not have good disease control despite maximum treatment. Of the 262 patients with good disease control, 100 (38.2\%) did not use any medication according to the stepped-care therapy rules for asthma. Furthermore, 49 (18.7\%) were treated according to step $1,110(42.0 \%)$ according to step 2, $6(2.3 \%)$ according to step 3 , and $1(0.4 \%)$ according to step 4.
In Tables 6 and 7, determinants of several patient groups are studied both bivariately and multivariately. Patients with good disease control not using any anti-asthma medication did not statistically significantly differ from patients with good disease control using anti-asthmatic medication, on a wide variety of characteristics, except for that they were more often male $(O R=1.64(0.99-2.71))$ (data not shown). Compared to patients with good asthma control using anti-asthmatic medication (Table 7), patients not adequately controlled were (independently) older, less well educated, younger when their pulmonary complaints started, and had a more severe dyspnea grade. In addition, they had poorer HRQoL (Table 6). Furthermore, wheezing most days and nights was more often found in patients who might gain most from changing treatment when compared to patients with good asthma control. Patients in whom adequate control might not be achieved by changing treatment more often presented with sputum production when compared to patients with good disease control and, although not statistically significant $(P=0.06)$, they were less often ex-smokers than 'never smokers'.

Table 5 Level of disease control according to 'worst category' vs. medical treatment: number of asthma patients $(n=661)$.

\begin{tabular}{llllll}
\hline Disease control & \multicolumn{3}{l}{ Medical treatment } & & \\
\cline { 2 - 6 } & Step 0 & Step 1 & Step 2 & Step 3 & Step 4 \\
\hline Good disease control & $100^{\mathrm{c}}$ & $49^{\mathrm{c}}$ & $73(+33)^{\mathrm{c}}$ & $6^{\mathrm{c}}$ & $1^{\mathrm{c}}$ \\
Mildly reduced disease control & $3^{\mathrm{d}}$ & $25^{\mathrm{d}}$ & $32(+12)^{\mathrm{d}}$ & $10^{\mathrm{d}}$ & $2^{\mathrm{f}}$ \\
Moderately reduced disease control & $28^{\mathrm{d}}$ & $35^{\mathrm{d}}$ & $100(+27)^{\mathrm{d}}$ & $39^{\mathrm{e}}$ & $6^{\mathrm{f}}$ \\
Poor disease control & $9^{\mathrm{d}}$ & $11^{\mathrm{d}}$ & $40(+11)^{\mathrm{b}, \mathrm{e}}$ & $9^{\mathrm{e}}$ & $0^{\mathrm{f}}$ \\
\hline
\end{tabular}

a Corticosteroids used 'when necessary' are considered as Step 2 care, but are showed separately in parenthesis.

${ }^{b}$ Of these patients, eight use corticosteroid when necessary and three use long-acting $\beta 2$-agonists only.

${ }^{\mathrm{c}} n=262$.

${ }^{\mathrm{d}} n=292$.

e $n=99$.

f $n=8$. 
Table 6 Bivariate multinomial logistic regression analyses with different groups according to disease control and medical treatment (see Tables 2 and 5) as the dependent variable (good asthma control is reference group) and characteristics as the independent variables.

\begin{tabular}{|c|c|c|}
\hline & \multicolumn{2}{|c|}{ Patient groups (reference group: good asthma control) } \\
\hline & $\begin{array}{l}\text { Inadequate disease control: } \\
\text { change in treatment required; } \\
\text { OR }(95 \% \mathrm{Cl}), n=292\end{array}$ & $\begin{array}{l}\text { Inadequate disease control: } \\
\text { adequate control might not be } \\
\text { achieved; OR }(95 \% \mathrm{Cl}), n=99\end{array}$ \\
\hline Age $\geq 45$ years (reference: $<45$ years) & $2.14(1.44-3.19)$ & $3.50(2.07-5.91)$ \\
\hline Male gender (reference: female) & $0.90(0.60-1.33)$ & $0.79(0.47-1.33)$ \\
\hline \multicolumn{3}{|l|}{ Educational level } \\
\hline Low (reference: high) & $5.06(2.02-12.68)$ & $12.41(4.51-34.13)$ \\
\hline Medium & $1.38(0.91-2.09)$ & $1.57(0.87-2.84)$ \\
\hline \multicolumn{3}{|l|}{ Co-morbidity } \\
\hline Present (reference: not present) & $1.31(0.86-1.98)$ & $2.14(1.25-3.66)$ \\
\hline Missing & $0.78(0.33-1.84)$ & $2.61(1.03-6.60)$ \\
\hline \multicolumn{3}{|l|}{ Smoking status } \\
\hline Ex (reference: never smoker) & $1.04(0.65-1.65)$ & $0.67(0.35-1.29)$ \\
\hline Current & $1.49(0.89-2.48)$ & $1.53(0.81-2.89)$ \\
\hline Missing & $0.86(0.39-1.91)$ & $1.41(0.56-3.54)$ \\
\hline $\begin{array}{l}\text { Presence of chronic cough } \\
\text { (reference: not present) }\end{array}$ & $1.50(1.00-2.26)$ & $2.35(1.40-3.95)$ \\
\hline $\begin{array}{l}\text { Presence of sputum production } \\
\text { (reference: not present) }\end{array}$ & $1.56(1.02-2.40)$ & $2.61(1.53-4.44)$ \\
\hline \multicolumn{3}{|l|}{ Wheeze } \\
\hline Ever (reference: never) & $1.51(0.89-2.58)$ & $1.03(0.52-2.02)$ \\
\hline Most days/nights & $3.61(1.69-7.70)$ & $2.91(1.17-7.19)$ \\
\hline \multicolumn{3}{|l|}{ Dyspnea } \\
\hline Grade 1 (reference: Grade 0) & $1.50(0.95-2.39)$ & $2.04(1.05-3.93)$ \\
\hline Grade 2 & $2.00(0.91-4.37)$ & $2.80(1.00-7.82)$ \\
\hline Grade 3 & $3.59(1.96-6.60)$ & $8.09(3.90-16.81)$ \\
\hline \multicolumn{3}{|l|}{ Allergy } \\
\hline Present (reference: not present) & $0.79(0.52-1.20)$ & $0.40(0.24-0.69)$ \\
\hline Missing & $0.43(0.21-0.85)$ & $0.34(0.14-0.84)$ \\
\hline $\begin{array}{l}\text { Age at onset of pulmonary } \\
\text { complaints } \geq 26 \text { years } \\
\text { (reference: }<26 \text { years) }\end{array}$ & $0.93(0.63-1.36)$ & $1.16(0.70-1.92)$ \\
\hline \multicolumn{3}{|l|}{ Compliance $^{\mathrm{a}}$} \\
\hline Not compliant (reference: compliant) & $1.14(0.65-1.98)$ & $0.51(0.28-0.95)$ \\
\hline Missing & $1.10(0.65-1.87)$ & $0.12(0.06-0.25)$ \\
\hline \multicolumn{3}{|l|}{ Inhalation technique ${ }^{\mathrm{b}}$} \\
\hline Poor (reference: good) & $1.17(0.63-2.19)$ & $1.72(0.78-3.79)$ \\
\hline Missing & $1.35(0.89-2.04)$ & $1.71(0.99-2.97)$ \\
\hline \multicolumn{3}{|l|}{ HRQoL ${ }^{c}$} \\
\hline Poor, score $\geq 13$ (reference: score $<13$ ) & $4.05(2.63-6.23)$ & $6.21(3.45-11.17)$ \\
\hline Missing & $2.22(1.11-4.45)$ & $3.71(1.53-9.04)$ \\
\hline
\end{tabular}


Table 7 Multivariate multinomial logistic regression analyses with different groups according to disease control and medical treatment (see Tables 2 and 5 ) as the dependent variable (good asthma control is reference group) and characteristics as the independent variables ${ }^{\mathrm{a}}$.

\begin{tabular}{|c|c|c|}
\hline & \multicolumn{2}{|c|}{ Patient groups (reference group: good asthma control) } \\
\hline & $\begin{array}{l}\text { Inadequate disease control: } \\
\text { change in treatment required; } \\
\text { OR }(95 \% \mathrm{Cl}), n=292\end{array}$ & $\begin{array}{l}\text { Inadequate disease control: } \\
\text { adequate control might not be } \\
\text { achieved; OR }(95 \% \mathrm{Cl}), n=99\end{array}$ \\
\hline Age $\geq 45$ years (reference: $<45$ years) & $2.30(1.38-3.85)$ & $3.57(1.63-7.82)$ \\
\hline $\begin{array}{l}\text { Educational level } \\
\text { Low (reference: high) } \\
\text { Medium }\end{array}$ & $\begin{array}{l}2.86(1.06-7.72) \\
1.36(0.87-2.11)\end{array}$ & $\begin{array}{l}9.20(2.64-32.06) \\
1.16(0.58-2.31)\end{array}$ \\
\hline $\begin{array}{l}\text { Smoking status } \\
\text { Ex (reference: never smoker) } \\
\text { Current } \\
\text { Missing }\end{array}$ & $\begin{array}{l}- \\
- \\
-\end{array}$ & $\begin{array}{l}0.46(0.21-1.03) \\
1.49(0.68-3.25) \\
1.12(0.35-3.55)\end{array}$ \\
\hline $\begin{array}{l}\text { Presence of sputum production } \\
\text { (reference: not present) }\end{array}$ & - & $2.30(1.20-4.40)$ \\
\hline $\begin{array}{l}\text { Wheeze } \\
\text { Ever (reference: never) } \\
\text { Most days/nights }\end{array}$ & $\begin{array}{l}1.62(0.91-2.87) \\
2.76(1.39-7.15)\end{array}$ & $\begin{array}{l}- \\
-\end{array}$ \\
\hline $\begin{array}{l}\text { Dyspnea } \\
\text { Grade } 1 \text { (reference: Grade 0) } \\
\text { Grade } 2 \\
\text { Grade } 3\end{array}$ & $\begin{array}{l}1.41(0.86-2.29) \\
1.40(0.61-3.21) \\
2.94(1.55-5.58)\end{array}$ & $\begin{array}{l}1.64(0.78-3.44) \\
0.84(0.24-2.92) \\
6.51(2.84-14.96)\end{array}$ \\
\hline $\begin{array}{l}\text { Age at onset of pulmonary } \\
\text { complaints } \geq 26 \text { years } \\
\text { (reference: }<26 \text { years) }\end{array}$ & $0.53(0.33-0.87)$ & $0.35(0.16-0.74)$ \\
\hline
\end{tabular}

Odds Ratios (ORs) are presented $(n=653)$.

a No association is found with age, co-morbidity, chronic cough, allergy, complianc, inhalation technique. HRQoL is not included in the multivariate model.

\section{Discussion}

This study proposes a model to define the level of disease control in adult asthma patients in conjunction with the level of medical treatment, in order to assess which patients are inadequately controlled and which of these patients might benefit from changing treatment. Applying this model to asthma patients from Dutch general practices participating in an observational study on the course of asthma, it appeared that a substantial proportion of asthma patients was inadequately controlled. Approximately $60 \%$ had mildly reduced to poor disease control, of whom $73 \%$ might benefit from changing treatment, while only $2 \%$ were already maximally treated. Compared to patients with good disease control, patients inadequately controlled were usually older, less well educated, younger at onset of pulmonary complaints, and in addition had more severe dyspnea and poorer health-related quality of life.
Since no consensus exists on the assessment of disease control, we used the classification rules of the Expert Panel Report II [11]. Although these classification rules are not validated, they are widely accepted for categorising disease severity. Despite the fact that the Expert Panel Report II did not include the use of $\beta 2$-agonists, we, as well as others $[12,14,15]$, believe that this variable is a relevant marker of disease control. As explained well by Colice et al. [12], as asthma worsens, patients could either experience more troublesome symptoms or use $\beta 2$-agonists more regularly. Furthermore, excessive use of $\beta 2$-agonists combined with under-use of corticosteroids is found to result in greater asthma related morbidity $[15,16]$. The model used to define disease control in this study (combining several parameters and then using the worst categorisation) maximises the identification of treatment inadequacy. So although treatment might have partly been effective in terms of improvement of some parameters, it is regarded as 
inadequate until all parameters are improved. Like Colice et al. [12], we found a poor correlation between individual variables in categorising the level of disease control in asthma patients, supporting the fact that all variables are important for categorisation of disease control. The poor association between pulmonary function and respiratory symptoms in asthma patients [2], furthermore supports the assumption that all aspects of disease control should be taken into account in the assessment of disease control. A patient with normal pulmonary function who has severe respiratory complaints to the extent that he or she regularly awakes at night and/or is forced to refrain from his or her normal activities, should not be regarded as well controlled based on pulmonary function alone. However, whether or not the model we used to define disease control is too strict, implying that the number of patients inadequately treated is overestimated, is for the reader to decide.

A part $(15 \%)$ of the asthma patients included in this study appeared to have good disease control while they did not use anti-asthma medication. These patients did not differ, besides the fact that they were more often male, from asthma patients with good asthma control using anti-asthma medication. It is possible that some patients are falsely labelled as asthma; however, since asthma is characterised by periodical complaints, it seems more likely that these patients had no complaints at the time of data collection.

The finding that a substantial proportion of patients with asthma may be inadequately controlled is supported by others in various countries and time periods $[1,14,17-20]$. Selection bias may have affected our results in two ways. Firstly, excluded patients tended to use less medication than included patients. It seems, therefore, likely that participating patients were less healthy than not participating patients, thus resulting in an overestimation of the number of patients inadequately controlled. Secondly, it is possible that participating practices were more motivated to provide good care for their patients, resulting in an underestimation of the number of inadequately controlled patients in the general population.

Besides global disease severity and level of medical treatment, other factors such as patients' compliance with the use of medication, inhalation technique, and patients' behaviour in avoiding environmental exposure, influence the level of disease control in asthma patients. Bivariate analyses show that compliant patients are more often patients in which adequate control might not be achieved as concluded by the large discrepancy between medication use and disease control. Dekker et al. [21] found that compliant patients had daily symptoms more often than non-compliant patients. A plausible explanation is that the presence of symptoms motivates patients to be more compliant. However, this study uses self-report of compliance which may well provide an overestimation of compliance [22]. Hypothesising that over-estimating compliance is related to over-reporting medication use might explain why compliant patients have inadequate disease control despite the fact that they report that they use medication.

Under-reporting of symptoms may be a reason why asthma patients are not adequately controlled. In a large survey in Europe [1] it was found that approximately $50 \%$ of asthma patients who reported severe persistent symptoms considered their asthma to be completely or well controlled. Consequently, a physician should take an active role in assessing symptoms of asthma, instead of waiting for them to be spontaneously mentioned [23]. It should, however, be noted that some patients may have preferred to accept symptoms at the level at which they are experienced rather than take additional treatment. In addition, some patients may previously have tried more intensive treatment and found it inadequate. Patient's dissatisfaction with asthma treatment is found to be associated with poor disease control, problems with the process of care, and problems related to patients' belief in their medication. More personal care may improve satisfaction and also disease control [24].

It is thought that anywhere between 1 and 15\% of asthma patients have severe asthma responding poorly to anti-asthmatic drugs [25]. This is in accordance with results from our study; $8(1.2 \%)$ patients had poorly controlled asthma despite maximal treatment and an additional 99 (15\%) patients were defined as under-treated patients in which adequate control might not be achieved by increasing treatment.

The level of disease control may determine, in conjunction with other patient factors, the healthrelated quality of life (HRQoL) of a patient. This is confirmed in our analyses as HRQoL is strongly associated with the inadequate control. Also others [26] found disease control in asthma patients to be associated with HRQoL.

The finding that older age is associated with inadequate control of asthma, might be explained by the finding that older patients generally have a more blunted perception of their pulmonary obstruction [27-29]. In addition, Weiner et al. [29] report that particularly older patients with long-standing disease had less pulmonary complaints irrespective of the level of pulmonary obstruction. This supports our finding that a younger 
age at onset of pulmonary complaints is associated with inadequate control after adjusting for other variables such as age. The fact that reporting more severe dyspnea was associated with inadequate control is not really surprising, but it does support the use of a short validated questionnaire to assess dyspnea as a sensitive instrument to identify patients with inadequate asthma control. The finding that patients with a lower educational level are more often inadequately controlled is in accordance with Watts et al. [30] who found that asthma patients in the lower social class were less likely to fill their prescriptions compared to other groups, possibly due to financial difficulties, disagreement with diagnosis, or lack of understanding. Poorer environmental conditions or reduced capability of adequate self-management might be additional explanations.

In conclusion, a substantial proportion of asthma patients primarily treated in general practice were inadequately controlled according to our criteria. Assessing patients' disease control together with the level of medical treatment may help to gain insight into the effectiveness of current disease management. Improving disease control in asthma patients is likely to improve the health-related quality of life of these patients.

\section{References}

[1] Rabe KF, Vermeire PA, Soriano JB, Maier WC. Clinical management of asthma in 1999: the Asthma Insights and Reality in Europe (AIRE) study. Eur Respir J 2000;16: 802-7.

[2] Wijnhoven HA, Kriegsman DM, Hesselink AE, Penninx BW, de Haan M. Determinants of different dimensions of disease severity in asthma and COPD: pulmonary function and health-related quality of life. Chest 2001;119: 1034-42.

[3] Geijer RM, Thiadens HA, Smeele IJ, Sachs AP, Bottema BJ, van Hensbergen W, et al. Guidelines of the Dutch College of General Practitioners: diagnosis of asthma and COPD in adults (Dutch) [in Dutch: NHG-Standard COPD en Asthma bij volwassenen: Diagnostiek]. Huisarts Wet 1997;40:41629.

[4] American Thoracic Society. Standardization of spirometry-1987 update. Am Rev Respir Dis 1987;136:1285-98.

[5] Quanjer PH, Tammeling GJ, Cotes JE, Pedersen OF, Peslin R, Yernault JC. Lung volumes and forced ventilatory flows. Report Working Party Standardization of Lung Function Tests, European Community for Steel and Coal. Official Statement of the European Respiratory Society. Eur Respir J 1993;6:5-40.

[6] Gijer RM, Van Hensbergen W, Bottema BJ, van Schayk CP, Sachs AP, Smeele IJ, et al. Guidelines of the Dutch College of General Practitioners: treatment of asthma in adults [in Dutch: NHG-Standard asthma bij volwassenen: Behandeling]. Huisarts Wet 1997;40:443-54.

[7] Hesselink AE, Penninx BW, Wijnhoven HA, Kriegsman DM, van Eijk JTh. Determinants of incorrect inhalation tech- nique in patients with asthma and COPD. Scand J Prim Health Care 2001;19:255-60.

[8] Maillé AR, Koning CJ, Zwinderman AH, Willems LN, Dijkman $\mathrm{JH}$, Kaptein AA. The development of the 'Quality-of-life for Respiratory Illness Questionnaire (QOL-RIQ)': a disease specific quality-of-life questionnaire for patients with mild to moderate chronic non-specific lung disease. Respir Med 1997;91:297-309.

[9] Matricardi PM, Nisini R, Pizzolo JG, D'Ametio R. The use of Phadiatop in mass-screening programmes of inhalant allergies: advantages and limitations. Clin Exp Allergy 1990;20:151-5. IN W

[10] văn der Lende R, Orie NG. The MRC-ECCS questionnaire on respiratory symptoms (use in epidemiology). Scand $J$ Respir Dis 1972; 53:218-26.

[11] National Heart, Lung, and Blood Institute. Expert Panel Report II: guidelines for the diagnosis and management of asthma. National Institutes of Health pub. no. 97-4051. Bethesda, MD; 1997.

[12] Colice GL, Burgt JV, Song J, Stampone P, Thompson PJ. Categorizing asthma severity. Am J Respir Crit Care Med 1999;160:1962-7.

[13] Cohen J. A coefficient of agreement for nominal scales. Educational and psychological measurement 1960;20:3746.

[14] Walsh LJ, Wong CA, Cooper S, Guhan AR, Pringle M, Tattersfield AE. Morbidity from asthma in relation to regular treatment: a community based study. Thorax 1999;54:296-300.

[15] Anis AH, Lynd LD, Wang XH, King G, Spinelli JJ, Fitzgerald $M$, et al. Double trouble: impact of inappropriate use of asthma medication on the use of health care resources. CMAJ 2001;164:625-31.

[16] Shelley M, Croft P, Chapman S, Pantin C. Is the quality of asthma prescribing, as measured by the general practice ratio of corticosteroid to bronchodilator, associated with asthma morbidity? J Clin Epidemiol 2000;53:121721.

[17] Kaptein AA, Dekker FW, Gill K, van der Waart MA. Undertreatment of asthma in Dutch general practice. Fam Pract 1987;4:219-25.

[18] Bousquet J, Knani J, Henry C, Liard R, Richard A, Michel FB, et al. Undertreatment in a nonselected population of adult patients with asthma. J Allergy Clin Immunol 1996;98:51421.

[19] Cerveri I, Zoia MC, Bugiani M, Corsico A, Carosso A, Piccioni $\mathrm{P}$, et al. Inadequate antiasthma drug use in the north of Italy. Eur Respir J 1997;10:2761-5.

[20] Ciprandi G, Vizzaccaro A, Cirillo I, Tosca M, Passalacqua G, Canonica GW. Underdiagnosis and undertreatment of asthma: a 9-year study of Italian conscripts. Int Arch Allergy Immunol 2001;125:211-5.

[21] Dekker FW, Dieleman FE, Kaptein AA, Mulder JD. Compliance with pulmonary medication in general practice. Eur Respir J 1993;6:886-90.

[22] Cochrane GM, Horne R, Chanez P. Compliance in asthma. Respir Med 1999;93:763-9.

[23] Kips JC, Pauwels RA. Asthma control: where do we fail? Eur Respir J 2000;16:797-8.

[24] Markson LE, Vollmer WM, Fitterman L, O'Connor E, Narayanan $S$, Berger $M$, et al. Insight into patient dissatisfaction with asthma treatment. Arch Intern Med 2001;161:379-84.

[25] Weissler JC. Syndromes of severe asthma. Am J Med Sci 2000;319:166-76.

[26] Vollmer WM, Markson LE, O’Connor E, Frazier EA, Berger M, Buist AS, et al. Association of asthma control with health 
care utilization and quality of life. Am J Respir Crit Care Med 1999;160:1647-52.

[27] Connolly MJ, Crowley JJ, Charan NB, Nielson CP, Vestal RE. Reduced subjective awareness of bronchoconstriction provoked by methacholine in elderly asthmatic and normal subjects as measured on a simple awareness scale. Thorax 1992;47:410-3.

[28] Bellia V, Cuttitta G, Cibella F, Scichilone N, Mancuso G, Vignola $A M$, et al. Effect of ageing on peak expiratory flow variability and nocturnal exacerbations in bronchial asthma. Eur Respir J 1997;10:1803-8.

[29] Weiner P, Magadle R, Waizman J, Weiner M, Rabner M, Zamir D. Characteristics of asthma in the elderly. Eur Respir J 1998;12:564-8.

[30] Watts RW, McLennan G, Bassham I, el-Saadi O. Do patients with asthma fill their prescriptions? A primary compliance study. Aust Fam Physician 1997;26:S4-6.

\section{Available online at www.sciencedirect.com $\mathrm{N} / \mathrm{Y}$

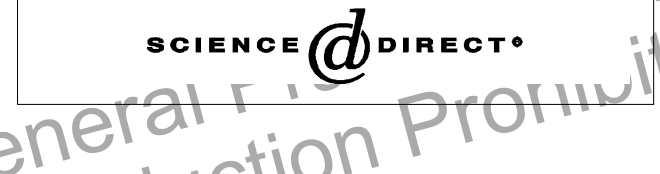

